\title{
Cross-infection experiments with Australian Perkinsus species
}

\author{
C. L. Goggin, K. B. Sewell, R. J. G. Lester \\ Department of Parasitology, University of Queensland, Brisbane, Queensland 4067, Australia
}

\begin{abstract}
Infections of Perkinsus spp. were initiated in 9 mollusc species using zoospores from cultured prezoosporangia held in petri dishes containing seawater We transferred parasites isolated from bivalves to gastropods and vice versa. Isolates from tropical, subtropical and temperate hosts were transferred to mollusc hosts from different climate origins. Some hosts, e.g. Saccostrea commercialis, were largely refractory, with only light infections developing in a few molluscs. Other hosts, e.g. Anadura trapezia and Pinctada sugillata, became heavily infected. An experimental infection in one A. trapezia endured in the laboratory for 7 mo
\end{abstract}

\section{INTRODUCTION}

Perkinsus marinus (Mackin et al. 1950) was described from Crassostrea virginica. Ray (1954) reported infections in Ostrea lurida and White et al (1987) recently found it in a pyramidellid gastropod that had fed on an infected $C$, virginica. The only other named species of Perkinsus, $P$, olseni, was described from the gastropod Haliotis rubra by Lester \& Davis (1981). Prezoosporangia, belonging to what appear to be other Perkinsus species, have been observed in 21 species of bivalve in North America (Andrews 1954 , Ray 1954), 6 in the Mediterranean (da Ros \& Canzonier 1985) and 30 in Australia (Goggin \& Lester 1987).

Structural differences that would enable the separation of Perkinsus species have not yet been recognised (Perkins in press) and cross-infection experiments with various isolates have, to date, been unsuccessful, suggesting strong host specificity. Experimental transmission between specimens of Crassostrea virginica has been accomplished by several methods: by adding minced, infected, oyster tissue to the aquarium (Ray \& Mackin 1954); by putting infected aysters in the aquarium alongside uninfected individuals (Ray 1954); by adding water from infected aquaria (Mackin 1952); and by injecting infected tissue (Mackin et al. 1953). However, Ray (1954) was unable to transfer the parasite via injection from Macoma balthica to either Crassostrea virginica, Venus mercenaria or Mya arenaria, or from $C$. virginica to $V$. mercenaria or $M$. arenaria. He concluded that this was due to the rigid host specificity of the parasite. Andrews \& Hewatt (1957) also injected infected $C$. virginia tissue into $V$. mercenaria and furthermore fed them tissue from infected $M$. balthica, but were unable to detect any infection after 1 mo. Lester \& Davis (1981) were unable to transmit $P$. olseni from Haliotis rubra to the Australian commercial oyster Saccostrea commercialis.

The work described below was undertaken to clarify the species affinities of the isolates of Perkinsus spp. we found in Australia (Goggin \& Lester 1987, Lester et al. 1988).

\section{MATERIALS AND METHODS}

Isolates of Perkinsus spp. were obtained from the following molluscs and locations: Tridacna gigas, Orpheus Island, Queensland (Qld); Chama pacificus and Tridacna maxima, Heron Island reef, Qld; Barbatia corallicola and T. crocea, Lizard Island reef, Qld; blood cockle Anadara trapezia, Wynnum in Moreton Bay, Qld (all bivalves); and abalone Haliotis spp. (gastropods), western Gulf of St Vincent, South Australia. Uninfected molluscs were obtained from Lizard Island, (Saccostrea cuccullata), Moreton Bay (Pinctada sugillata, hairy mussel Trichomya hirsuta [bivalves], Pyrazus ebinenus [gastropod]), Deception Bay in Moreton Bay (Anadara trapezia), Terranora Lakes, New South Wales (N.S.W.) (Isognomon sp., Saccostrea commercialis [bivalves]) and West Island, South Australia (Haliotis spp.) (Fig. 1, Sites 1 to 7 ). 


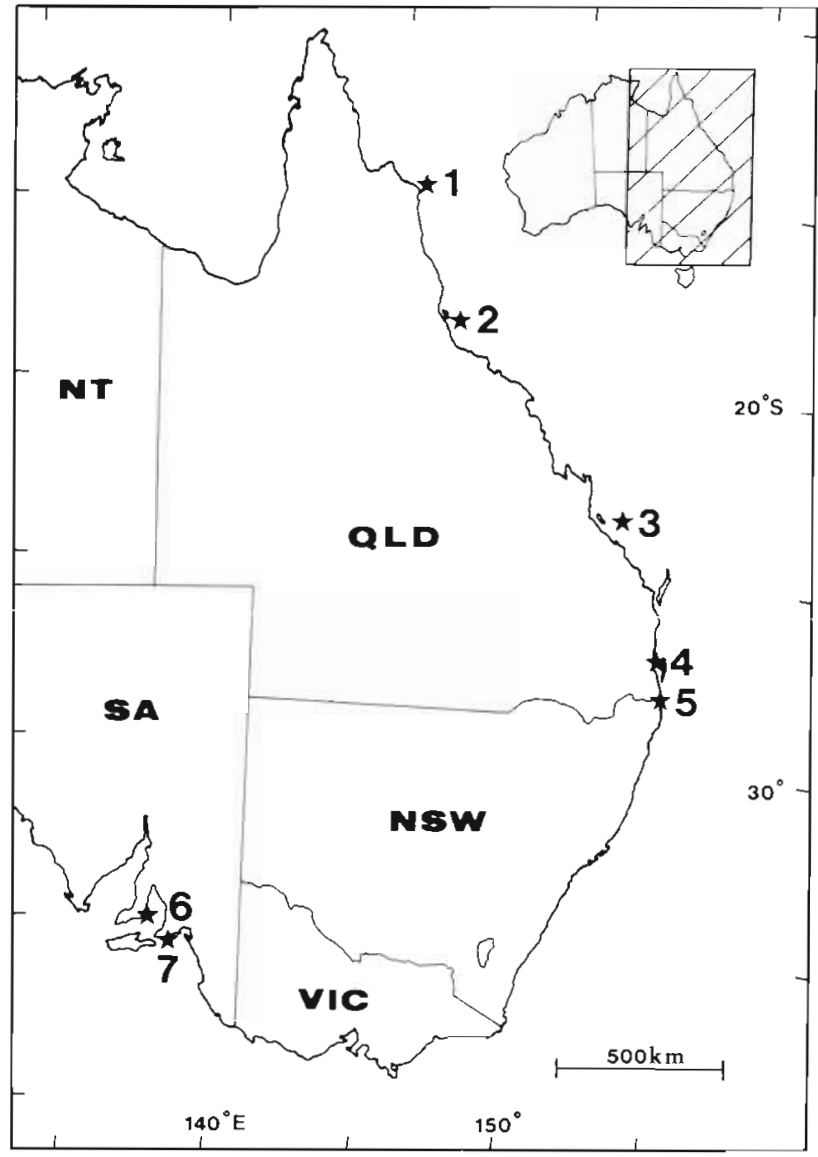

Fig. 1. Map of eastern Australia showing the 7 sites where experimental molluscs were collected. 1: Lizard Island; 2: Orpheus Island; 3 : Heron Island; 4: Moreton Bay; 5 . Terranora Lakes; 6: western Gulf of St Vincent; 7: West Istand

In preliminary experiments, tissue from Chama pacificus infected with Perkinsus sp. was injected into Saccostrea commercialis through a $26 \mathrm{G}$ needle. Two tests were done at $20^{\circ} \mathrm{C}$ and two at $27^{\circ} \mathrm{C}$ (Table 1).

All further infections with Perkinsus spp. were initiated as follows: parasites were isolated from infected molluscs by culturing tissue in fluid thioglycollate medium (Ray 1966). After 4,5 or 7 d, infected tissue was removed from the medium and transferred to $10 \mathrm{~cm}$ diam. petri dishes of seawater. Heavily infected tissue was teased apart to liberate prezoosporangia. Excess tissue was removed and prezoosporangia allowed to settle on the bottom of the dish for up to $12 \mathrm{~h}$. The surface water was then decanted to leave the prezoosporangia, which adhered to the glass. Seawater was changed daily by upending the dish and refilling The development of prezoosporangia to zoosporangia was monitored with a compound microscope. When motile zoospores were visible within zoosporangia the seawater was poured off and dishes immersed in aquaria holding test molluscs. At the same time, flow- through water in the aquaria was stopped. Dishes were left until all zoosporangia had discharged (up to $96 \mathrm{~h}$ ) to allow for maximum infestation. Water in the control aquarium of each experiment was also turned off during the infection period. Test, and an equal number of control, molluscs were then maintained at either $20^{\circ} \mathrm{C}$ (all experiments with abalone and some with Anadara trapezia, see Table 1) or $27^{\circ} \mathrm{C}$ (all other experiments). Molluscs were killed after 2 to 196 d. For individual molluscs, infections were assessed essentially as described by Quick (1971). We defined 7 levels of

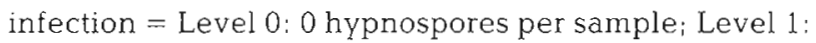
1 to 10 per sample; Level 2: 11 to 100 per sample; Level 3: 101 to 1000 per sample; Level 4: 31 to 300 per field $5 \mathrm{~mm}$ in diam.; Level 5: 301 to 1000 per $5 \mathrm{~mm}$ field; and Level ô: nllore ilıal 1001 per $5 \mathrm{~mm}$ field (ca $0,0.005$, $0.04,0.8,8,33$ and 102 hypnospores $\mathrm{mm}^{-2}$, respectively). Samples included the whole mollusc, except for abalone where a standard tissue section was taken just posterior to the head on the left side. This section included pieces of gill, foot, digestive gland, muscle and mantle. For each experiment, an average level of infection (between 0 and 6) was calculated as the sum of infection levels of all individuals divided by the number of molluscs exposed to infection (Table 1). After thioglycollate culture, all isolates were allowed to develop in seawater as a test of their viability.

\section{RESULTS}

The introduction of petri dishes coated with Perkinsus spp. into aquaria was an effective and rapid method of producing infections in receptive molluscs without compromising their fitness. Most inter-specific infections attempted using this method were successful (Table 1) although the level of infection and number of positive molluscs varied. Saccostrea commercialis and Trichomya hirsuta were largely refractory. Few of these became infected and most that did had low levels of infection (Levels 0 to 3). The heaviest infections seen in $S$. commercialis were in individuals held for longer than 2 mo and infected with Perkinsus sp. from Anadara trapezia (see Table 1) where $1 / 10$ and $3 / 20$ oysters, respectively, registered Level 4 infections. A. trapezia and Pinctada sugillata were particularly susceptible to infection. Perkinsus sp. originally isolated from the bivalves A trapezia, Chama pacificus, Tridacna gigas, $T$. crocea and $T$. maxima were able to be transferred to, and developed in, the gastropods Haliotis laevigata, $H$ scalaris and Pyrazus ebinenus (Table 1). Infections isolated from abalone held at $20^{\circ} \mathrm{C}$ and cultured at $27^{\circ} \mathrm{C}$ infected Moreton Bay bivalves. Perkinsus spp. isolates taken from Chama pacificus from Heron Island were capable of infecting a range of Moreton Bay bivalves. 
Perkinsus sp. isolated from $T$. gigas from Orpheus Island was also able to infect Moreton Bay bivalves held at $27^{\circ} \mathrm{C}$ No infections were found in any of the controls.

Very low levels of infection were transferred in 2 preliminary trials by injecting infected, minced tissue of Chama pacificus into Saccostrea commercialis, though injection of tissue often led to death of the host. Two experiments conducted at Lizard Island Research Station were unsuccessful; infection was not transferred to $S$. cuccullata using zoospores cultured from Tridacna crocea or T. maxima (Table 1).

Infections were detected in experimental molluscs Pinctada sugillata after $1 \mathrm{~d}$ (2/4 had Level 1 infections, Table 1). One Anadara trapezia, experimentally infected with Perkinsus sp. from the same host species, remained infected for 7 mo in the laboratory at $20^{\circ} \mathrm{C}$.

In several cases, experimentally infected molluscs were used as a source of Perkinsus sp. to successfully infect further molluscs. For example, an isolate from Tridacna gigas was grown in Pinctada sugillata, reisolated and then used to infect other $P$. sugillata and 3 other species of mollusc (Table 1). An isolate, originally from Anadara trapezia (from Wynnum), was passaged 7 times through previously uninfected bivalves (Table 1).

Perkinsus schizonts in experimentally infected Anadara trapezia were almost always subepithelial. Few were observed deep in the tissue of the host.

\section{DISCUSSION}

The advantages of our infection method are that large numbers of animals can easily be infected with no mechanical damage to the host, and that high levels of infection can be achieved. The poor success rate of our initial inoculation experiments is in agreement with that of Ray (1954). At the time of his experiments he was unaware that the parasite produced zoospores and so, was unable to test this method of infection. Zoospores were first found by Perkins \& Menzel (1966)

The lack of schizonts deep in the tissue of Anadara trapezia suggests that infection in this host is via penetration and not per os (Lester et al. 1989). Perkinsus marinus, however, has been found in experimentally infected oysters Crassostrea virginica in the digestive epithelium, from the stomach to the rectal area and is assumed to enter the host primarily with the feeding current (Mackin 1951). It is not clear why schizonts in A. trapezia were only found just beneath the epithelium in our experimental infections, whereas in $C$. virginica and in naturally infected hosts we have examined, including A. trapezia, they multiply throughout the host tissues

The origin of the parasite (i.e. temperate, tropical or subtropical) did not affect the ability of the isolate to be transferred to molluscs from different localities. Isolates from gastropods (Haliotis laevigata) were transferred to bivalves, and vice versa, indicating a low level of host specificity for this (these) parasite(s). We found that the histological appearance of natural infections varied greatly in different host species and suggested at least 2 Perkinsus species were present on the Great Barrier Reef. We now plan to evaluate the histology of experimental infections and to compare the rates of development of prezoosporangia in seawater in order to develop criteria to separate species and strains. Serological and genetic studies will be possible once we have sufficient material in axenic culture.

Acknowiedgements. Fieici wuik un ilıe Great Bämier Reef was carried out at the Lizard and Heron Island Research Stations. For assistance in the field we thank the Queensland National Parks and Wildlife Service, Dr S. Shepherd and other officers of the South Australian Department of Fisheries, Mr A. Geering and $\mathrm{Mr} \mathrm{C}$. Johnson. Dr J. S. Lucas kindly supplied the hatchery reared Tridacna gigas. The project was funded by grants from the Fishing Industry Research Trust Account (FIRC 87/9) and the Australian Marine Sciences and Technologies Grants Scheme (MST A08600937).

\section{LITERATURE CITED}

Andrews, J. D. (1954). Notes on the fungus parasites of bivalve molluscs in Chesapeake Bay. Proc. natl Shellfish. Ass. 45: $157-163$

Andrews, J. D., Hewatt, W. G. (1957). Oyster mortality studies in Virginia If The fungus disease caused by Dermocystidium marinum in oysters in Chesapeake Bay. Ecol Monogr 27: 1-25

da Ros, L., Canzonier, W J. (1985). Perkinsus, a protistan threat to bivalve culture in the Mediterranean basin. Bull. Eur. Ass. Fish. Path. 5: 23-25

Goggin, C. L., Lester, R. J. G. (1987). Occurrence of Perkinsus species (Protozoa, Apicomplexa) in bivalves from the Great Barrier Reef. Dis. aquat. Org. 3: 113-117

Lester, R. J. G., Davis, G. H. G. (1981). A new Perkinsus species (Apicomplexa, Perkinsea) from abalone Haliotis ruber. J. invert Pathol. 37-181-187

Lester, R. J. G., Goggin, C. L., Sewell, K. B. (1989). Perkinsus in Australia. In: Cheng, T C., Perkins, F. O. (eds.) Pathology in marine aquaculture. Academic Press, New York, in press

Mackin, J. G. (1951). Histopathology of infection of Crassostrea virginica (Gmelin) by Dermocystidium marinum Mackin, Owen and Collier. Bull. mar. Sci Guif Caribb. 1. $72-87$

Mackin, J. G. (1952). A study of transmission of infective elements of Dermocystidium marinum by way of water currents. Texas A. and M. Research Foundation, Project 23. Technical Report No. 3

Mackin, J. G., Owen, H. M., Collier, A. (1950). Preliminary note on the occurrence of a new protistan parasite, Dermocystidium marinum $n$. sp. in Crassostrea virginica (Gmelin). Science 111. 328-329

Mackin, J. G., Ray, S. M., Boswell, J. L. (1953). Studies on the transmission and pathogenicity of Dermocystidium 
marinum. Texas A. and M. Research Foundation. Project 23. Technical Report 10: 1-12

Perkins, F. O. (in press). Structure of protistan parasites found in bivalve molluscs. In: Fisher, W. (ed.) Disease processes in marine bivalve molluscs. American Fisheries Society, Washington, D.C. Spec. publ.

Perkins, F. O., Menzel, R. W (1966). Morphological and cultural studies of a previously unreported stage in the life cycle of Dermocystidium marinum Mackin, Owen and Collier, in oysters. Science 116: 360

Quick, J. A., Jr. (1971). Pathological and parasitological effects of elevated temperatures on the oysters Crassostrea virginica, with emphasis on the pathogen Labyrinthomyxa marina. Marine Research Laboratory (St. Petersburg, Florida), Professional Papers Series 15: 105-171

Responsible Subject Editor: Dr A. K. Sparks, Seattle, Washington, USA
Ray, S. M. (1954). Biological studies of Dermocystidium marinum, a fungus parasite of oysters. Rice lnstitute Pamphlet, Special Issue

Ray, S. M. (1966). A review of the culture method for detecting Dermocystidium marinum with suggested modifications and precautions. Proc. natl Shellfish. Ass. 54. 55-69

Ray, S. M., Mackin, J. G. (1954). Studies on the transmission and pathogenicity of Dermocystidium marinum. Texas A and M. Research Foundation, Project 23, Technical Report No. 11

White, M. E., Powell, E. N., Ray, S. M., Wilson, E. A. (1987). Host-to-host transmission of Perkinsus marinus in oyster (Crassostrea virginica) populations by the ectoparasitic snail Boonea impressa (Pyramidellidae). J. Shellfish Res. 6: $1-5$

Manuscript first received: March 22, 1989

Revised version accepted: June 8, 1989 